\title{
Popular Surveillance of Contemporary Slavery
}

\section{| ${ }^{1}$ Luís Henrique da Costa Leão, ${ }^{2}$ Thomaz Ademar Nascimento Ribeiro |}

Abstract: Considering social movements $(\mathrm{MH})$ as agents for the production of information and actions that are fundamental to improve the health conditions of workers and their relevance in the history of health-work relations in Brazil, the article analyzes $\mathrm{MH}$ knowledge and practices related to collection, systematization, dissemination of information and intervention actions in contemporary slavery from the perspective of worker's health surveillance (VISAT). Exploratory research of a qualitative nature was carried out on discursive practices of MS in the struggle for the eradication of slave labor in Brazil. Interviews with activists, documents produced by MS and observation of meetings and seminars were analyzed here according to Foucault. The results demonstrate the existence of a popular surveillance of contemporary slave labor, operated by MS with pioneering and original mechanisms for collecting, systematizing and publicizing data on occurrences of slavery associated with intervention strategies to defend the lives of workers. It is concluded that this popular practice of slavery surveillance challenges the SUS to expand dialogues with different knowledge and MS to include the theme in its VISAT actions.

> Keywords: social movements; popular surveillance, health workers.

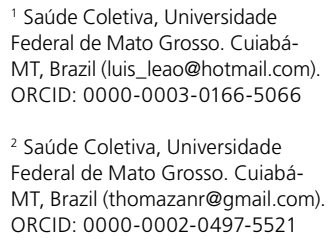

1 Saúde Coletiva, Universidade Federal de Mato Grosso. CuiabáMT, Brazil (luis_leao@hotmail.com). ORCID: 0000-0003-0166-5066

2 Saúde Coletiva, Universidade Federal de Mato Grosso. CuiabáMT, Brazil (thomazanr@gmail.com). ORCID: 0000-0002-0497-5521

Received: 29/05/2020 Approved: $15 / 10 / 2020$ Revised: 29/03/2021 


\section{Introduction}

This article addresses knowledge and practices of social movements (SMs) in the fight against contemporary slave labor (CSL) from the perspective of worker health surveillance (VISAT).

It is well known that even after the enactment of the abolition (Golden Law), slavery persisted in Brazilian society under new clothes. Those contemporary forms of slave labor started to be reported by syndicates, groups and SMs organized in the 1970 's, such as the Comissão Pastoral da Terra (CPT) (Pastoral Land Commission) and other movements linked to Liberation Theology, that fight for land and agrarian reform and they have been one of the major collective subjects in the front for CSL eradication (MARTINS, 2004). They developed strategies and accumulated concrete experiences of responses to this social problem, and the pressures exerted by them made the Brazilian government recognize the CSL in the 1990s and institutionalize state policies and actions.

This phenomenon needs more attention in the field of workers' health (WH), especially because until today the CSL is not an object of institutional actions and specific studies in this field (LEÃO, 2016). From the historical point of view, it is recognized that $\mathrm{WH}$ in Brazil has received great influence from workers, urban and industrial SMs, especially the Italian Model Worker that in the fight against the harmfulness of work environments has inspired new experiences in health-work relations (VASCONCELLOS; PAIVA, 2011). On the other hand, the activities of the SMs in rural areas inaugurated important initiatives of interest to workers' health during the same period, however they do not always receive the proper recognition in the history of the field of health-work relations in Brazil. This article seeks to fill this gap by rescuing and recognizing the struggle of the SMs of the field in defense of the lives of workers submitted to the CSL.

Contemporary slavery (CS) or contemporary slave labor are coercive ways of submitting workers to forced labor, exhausting days, degrading conditions, locomotion restriction due to debt, document retention, use of violence and human trafficking (BRAZIL, 2003). The terms most commonly used in the literature to refer to these forms of exploitation are unfree labor, slave-like labor, semi-slavery, debt bondage, modern slavery, white slavery, forced labor, and CSL (ESTERCI, 2008; FIGUEIRA, 2004; BALES, 1999; MARTINS, 2004). For Orlando Patterson 
(1982), in his relevant comparative analysis "Slavery and Social Death", slavery is one of the most extreme forms of domination and the power relations that characterize it are crossed by social, cultural, and psychological facets, constituted by violence, alienation, and dishonor capable of leading to the experience of social death.

This phenomenon has been the subject of attention and debate by international organizations so that, during the twentieth century, many declarations and normative conventions have been produced to combat it, like the ILO conventions on forced labor (no. 29 of 1930 and no. 105 of 1957) and the United Nations conventions on slavery of 1926 (which still defined it as property rights) and the abolition of practices analogous to slavery of 1956, as well as the Palermo Protocol of 2000, which deals with human trafficking.

From an academic point of view, the CSL is also the object of study in different disciplinary fields (History, Sociology, Law, Anthropology, Economy, Geography, etc.) under different theoretical-methodological approaches and, in the Brazilian scenario, relevant contributions from the Social Sciences point of view can be found in Figueira (2004) and Esterci (2008). At the international level, the publication of "Disposable People" (1999) gained notoriety opening even more academic debates on the subject. Bales (1999) characterizes the CS not from the point of view of property rights, but from the practices of control over workers/workers and the use of violence for profit. According to this author (BALES, 2007), the CS is linked to the economic development model of capitalist accumulation and to conflicts and ecological degradations, taking more fluid and less visible forms than in times when its existence was legally supported. It is estimated that 40.3 million people were in slavery in the year 2018 in the world and, in Brazil, 53,607 workers were rescued from these conditions from 1995 to 2018 (MPT, 2019).

The conditions of CS show it as an important public health problem, due to deaths and the severe levels of illness it produces in the working class, representing a niche of exposure to environmental and occupational risks that added to the physical violence, intense physical effort without possibilities of replacement of energy and poor conditions of food, water, housing, prevent the reproduction of the forces of workers (ZIMMERMAN; HOSSAIN; WATTS, 2011; LEÃO, 2016).

Reducing the occurrence of slave labor is, therefore, contributing to a healthier society. However, guidelines and surveillance strategies to reduce/control CS-related morbidity and mortality are lacking, even though the National WH Policy aims to 
strengthen VISAT including its collaboration to "identify and eradicate situations analogous to slave labor" (BRAZIL, 2012, p. 47).

VISAT, specifically, is a set of actions of investigation and intervention on work processes, in order to eliminate or control conditioning, risks, social and health vulnerabilities, following the principle of universality, multi-institutionality, social control, workers' participation and the transformative character of labor and health conditions, among others (BRAZIL, 1998).

In order to advance in the surveillance of slavery, VISAT needs closer approaches in actions confronting CSL as well as greater engagement of the academic actors in the production of knowledge. Few articles address the relationship between surveillance and CS, recognizing the merit of public health in identifying risk groups, risk assessment and control measures (TODRES, 2011), foreseeing a model of organized intervention in each stage of human trafficking (ZIMMERMAN; HOSSAIN; WATTS, 2011) and considering the importance of surveillance of working conditions in the CS and monitoring related health inequities (BENACH et al., 2012).

Considering the scarcity of Brazilian academic productions, few institutional initiatives of the health sector in CS surveillance and the experience of more than 40 years of the SMs in combating CSL, this article aims to analyze the practices and knowledge of the SMs related to the collection, systematization, dissemination of information and intervention action in contemporary slavery from the perspective of worker health surveillance.

\section{Theoretical-methodological trajectory}

This article is one of the results of the research project "Health Promotion and Surveillance of Workers in Context of Slavery: perspectives for the strengthening of intervention strategies", in which the Master's thesis entitled "Surveillance of Contemporary Slavery: knowledge and practices of social movements in Mato Grosso" was inserted, taken as one of the bases for the production of this text.

We sought to investigate theoretical approaches, knowledge and practices mobilized in the struggles for the eradication of the CSL from the perspective of actors from academia, SMs, state institutions and rescued workers, but for this article we present a focus on the perspective of the SMs who exert pressure to weaken the system of slave domination present in Brazilian society. 
The SMs are organizations and social groups that mobilize collective actions that challenge, question, and fight against a certain mode of widespread social domination. They have a socio-political and cultural character and favor different ways of claiming rights, elaborating demands, establishing resistance against oppressions, and building means of liberation (TOURAINE 2006; GOHN, 2011). We then sought to investigate the knowledge and practices of SMs engaged in the struggle against the CSL and for this we conducted a qualitative research of an exploratory type in the state of Mato Grosso because it is one of the Brazilian states with the highest prevalence of slavery and the presence of resistance-oriented SMs.

The fieldwork lasted one and a half years - from the second half of 2018 to the end of 2019 - and the data production consisted of the concomitant employment of (a) participant observation, (b) document analysis and (c) individual interviews.

(a) Participant observation aimed to get closer to SMs activists and verify their pronouncements in meetings, events, seminars and regional and national scientific meetings on the subject. This technique was carried out in five public events (symposium on slave labor organized by labor inspectors, forum on migration flows, national scientific meetings of the Contemporary Slave Labor Research Group -GPTEC-UFRJ- and seminar on combating CSL in MT). We adopt the use of field diaries to allow notes of our perceptions and also expressions of the SMs relative to the means and purposes of their forms of action.

(b) For documentary analysis we seek to map public materials written by SMs through informal interviews with SMs activists, talks with experts and research on the SMs website. The intention was to know written materials about the CSL (primers, notes, reports, news, forms, texts of CSL denunciations, etc.) We obtained access to a private collection of CPT with documents since the first denunciations made in the 1970s. Given the immense volume of materials found, we chose to make a thematic cutout, including in the sample only those documents whose central object was the CSL and used for training (description of the campaign and educational pamphlet), denunciation form (the standardized denunciation form and two pastoral letters) and publicization of data (9 Notebooks Conflicts in the Field - 2011 to 2019), reaching a total of 14 documents. We analyzed this material to verify what information was produced and what was its purpose. 
(c) Individual interviews were conducted with historical militants in the struggle against the CSL in Brazil and representatives of the SMs of defense of rural workers in the state of Mato Grosso. The criteria for inclusion of participants were: 1) being a member of the Ministry of Health and having experience in preventive actions, articulation, denouncements, attention and assistance in face of contemporary slavery problems, and 2) being a member of the movement for over six months. Nine people, six men and three women were heard, and the interviews lasted an average of 60 minutes and took place in environments provided by the interviewees themselves. We used the semistructured interview, composed of open questions about characteristics and procedures of the SMs action in the fight for the eradication of CS, especially regarding the production of information for intervention and eradication. All were recorded and transcribed in full.

The data production process was closed through saturation (FONTANELLA, 2011) and all the data from the interviews, documents and observations composed the corpus of this research.

For the analysis we organized the data and read in depth the interviews, documents and observations recorded, considering their interrelationship with socio-cultural, political and economic aspects. For this purpose, we used as bases the Discourse Analysis, from a Foucauldian perspective, which allowed us to know conditions, circumstances and transformations operated in the SMs activities around the CSL. In this way, we understand discourse not in a reduced way as mere proposition, sentence or speech, but as a set of statements (basic units of discourse) that are demarcated by regularities and supported by the same discourse formation (which operates on the principle of dispersion giving conditions for the emergence of different points of view, concepts, etc.) (FOUCAULT, 1969). Under this scope, we describe how the object of slave labor becomes the target of an intense production of knowledge and surveillance practices of the SMs in scenarios of economic and social conflicts that act in its emergence and origin.

The understanding of this phenomenon conformed to a "discursive practice" - which, according to Foucault, refers us to the historically determined rules in time-space and provides the conditions for the enunciative function - allowing us to analyze how the CSL emerges as a real and attention worthy element, around 
which social surveillance practices start to be woven. Thus, we do not seek to carry out an exegetical analysis of the corpus of research as one that seeks deep inner senses to discover new things enclosed there, but to describe enunciations that act to conform the CSL as an object of sociopolitical struggle and the forms that assume the strategies of movements.

We carry out the interpretation and discussion in light of the conception and principles of VISAT, circumscribing three categories adopted as central analyzers: Information (detection-identification of demand-problem, ways of producing knowledge to generate denunciations and making information available to society), intervention (inspection of work environments and educational processes to mitigate identified problems) and the principle of workers' participation/knowledge highlighting the leading role of social movements and groups as a fundamental element to know and transform socio-sanitary realities, developed in the approaches of Critical Epidemiology (BREILH, 2003), Popular (BROWN, 1992), Community (TOGNONI, 1997) and Civil (SEVALHO, 2016). These critical epidemiology movements have in common the recognition of the relevance of the voice of social groups and SMs in the production of information, prevention, defense and promotion of health and are opposed to traditional epidemiology based on statistics and bureaucratic technique, as well as closed to participation and popular knowledge.

The research followed the ethical aspects of the research in health according to the resolution 466/2012, being approved by the Committee of Ethics in Research of the Federal University of Mato Grosso, under opinion number 3,293,655. In the course of the article we cited only some literal fragments of the interviews, using fictitious names to preserve the anonymity of the subjects as well as quotations of public documents of the SMs.

\section{Results and Discussion}

\section{Making visible: the information generation process}

Information about the existence of the CSL began to appear on the national public scene due to the presence and practice of social and religious groups, engaged in the defense of workers' rights in the scenario of socio-territorial conflicts in the countryside in different regions of Brazil in the 1970s, especially in the Pastoral Land Commission (CPT), the Movement for Basic Education (MEB) and rural 
workers' unions. These social actors found themselves facing violence, exploitation, and countless violations of the dignity of poorer workers, peasants, traditional peoples, and family farmers in scenarios that symbolized a "powder keg", due to the exercise of power by large landowner capitalists in the pressures for territorial domination and control of land use.

Many workers fleeing the explorations and violence on the farms had only the Church to seek relief and the pastoral agents welcomed them, listening and offering support, food, lodging, security, comfort, conversation, help and possible protective strategies to prevent them from being assassinated. In this context they began the first records of testimonies of people submitted to the CSL.

As one interviewee points out, the agents let the worker speak freely about the working conditions experienced and "the diseases contracted at work, explain the symptoms, such as fever, give details and describe the escape, criminal issues and any aspect that demonstrated the violence, circumstances of murder, torture" (José).

In this work, the SMs recognized the worker submitted to slavery as a class, a category that has its own particularity (SILVA, 2016) and right to voice, therefore becoming reliable interlocutors for the workers (FIGUEIRA and PRADO, 2014). Their denunciations were a form of activist reaction to a context of class extermination (FREITAS E RIBEIRO, 2017). These agents were the first to collect, record, understand and transmit the "fundamental elements of the culture of the poor of the earth in the contemporary period of the history of social marginalization in Brazil" (MARTINS, 2004, p. 148).

Over the years of receiving workers, gathering information, and formulating denunciations, the CPT's methodologies and modes of operation have changed in an attempt to standardize the records and organize the information provided by workers. New means of contact with the workers were made available (for example, use of the telephone to receive complaints), strategic offices were created in regions where workers could be recruited and passed through (FIGUEIRA E PRADO, 2014), and a proper form was developed with registration fields on location, reported situation, number of workers involved, threats suffered, social and demographic profile of the victim, diseases and work accidents mentioned, among others - a kind of notification-registration form as a surveillance tool. The intention was to improve the generation of information and record as many elements as possible that the deponent could make available and thus provide better conditions to formulate 
complaints and subsidize the action of authorities (especially with the creation of the Mobile Labor Inspection Group in the 1990s) and also allowing for the accurate knowledge of this reality.

For the formulation of reports, SMs use not only the victims' narratives, but also secondary sources in materials such as newspapers, official documents, etc. After accessing this set of data, its registration and systematization, an informational flow is established in a collaborative network that allows the circulation of the knowledge generated between different bases in different regions of the country.

The information flow of CPT goes from its regional bases, which send data to the Dom Tomás Balduíno Documentation Center (CEDOC) in the city of Goiânia-GO, where they are systematized. These data are published in various forms and many of them are included in the annual publication entitled "Conflicts in the Countryside: Brazil," which functions as a memory and support against the countless human rights violations, considered by the SMs as "our most powerful weapon to denounce violence in the countryside in relation to slave labor" (Luiz).

The most recent publication of these notebooks provides an overview of the violence that occurred between 2010 and 2019 and points out that there were 1,377 conflicts involving labor causes in the countryside. Of these, 1,263 are related to the CSL, involving 26,369 workers and 2 murders were registered (CPT, 2020).

The work of generating and publicization of information formed one of the most important documentary collections on the struggles for land and forms of resistance by peasants, quilombolas, and native peoples in Brazil, in addition to leading to conquests of workers' rights and punishment of criminals (CPT, 2017). It is not only a matter of producing statistical data, but also of recording the history of struggle of an exploited class, that is excluded, and historically violated; of exposing the picture of the real situation, characteristics, forms, types, and impacts of the forms of slavery, giving public visibility to the populations affected, and of putting pressure on society and the State to defend the lives of the workers.

It is clear that there is a cycle of activities whose stages include: welcoming workers, listening to their reports, recording the details of the case, formulating and formalizing denunciations using secondary data as well, flow of information among SMs agents, organization, systematization, and publication of data at the national level, which aims to make visible the hidden violence as well as to be the basis for strategies for accurate repressive, punitive, and preventive interventions 
by institutions and civil society. This process becomes possible because there is a network of agents spread throughout Brazilian territory, living in the midst of land conflicts and alongside peasants, settlers, campers, family farmers, indigenous peoples, and rural workers, in well-organized communication and information flow as the fruit of a robust emancipatory commitment.

By considering surveillance as information for action, we know the difficulties of registering cases and analyzing the real incidence and prevalence of CS not only in Brazil, but also around the world. For this reason, the SMs, particularly the CPT, make an important contribution to unveiling this reality by helping in the process of highlighting the expressions and characteristics of the CSL in the Brazilian scenario, so that without the work of the SMs we would know very little about these contemporary forms of slavery in Brazil.

Therefore, this work of SMs surveillance is pioneering and relevant, because the information systems of the Health Surveillance in the Brazilian Unified Health System, although they include CSL notifications, cannot capture this reality. In fact, as Kevin Bales (2007) states in Ending Slavery, the cases of slave labor in Brazil go beyond the capacity of governments to deal with it and the CPT develops a vital work that deserves to be replicated around the world.

It is also important to point out that the speeches are not reduced to a "watch" in the sense of an "observation" restricted to recognizing the CSL, but incorporates the intervention with the purpose of transforming this reality.

\section{Transforming reality: intervention strategies}

The intervention actions involve interconnected axes of prevention of new cases, support to vulnerable communities and victims of slavery, development-participation in collective forums and collaboration in work environment inspection.

The logic of prevention that emerges in the SMs' discourse refers to strategies to reduce the "risk of slavery" and overcome the limitations of repressive actions, since they are pointed out as insufficient to solve the problem. According to data from the CPT itself, from 1995 to 2019 the operations of the Mobile Inspection Group (GEFM) rescued around 54,000 workers, but by themselves they cannot break the cycles of the CSL and avoid re-slavery, because "[...] the more the worker was liberated, the more others appeared, liberation itself is not a fight against slave labor" (João). Hence the relevance given to the processes of socio-cultural transformation by emancipatory 
education through campaigns, seminars and training aimed at reducing vulnerability so that people are "vaccinated" against the social disease of the CS.

A central campaign in this direction is called "An open eye to avoid becoming a slave", which has leaflets, posters and a didactic booklet known as "sanfoninha" (little accordion). The booklet reports on the genre of comics portraying the process of enticement and enslavement, and teaches ways to denounce, which authorities to appeal, etc. Materials like these are widely used in different regions of Brazil in formation processes that, while preventing, identify new cases by the process of critical reflection making workers "open their eyes" and recognizing the experience of CSL once lived:

Within this settlement of 173 families, a hundred and a few passed through slavery [...]. After we presented some situations of violence, about the whole reality of slave labor, one hundred and a few families said they had already experienced these situations of slave labor (Sebastião).

This conscientization process is directed to the different social strata (general population, workers, unions, public agencies, etc.), using different strategies (campaigns, seminars, visits to camps, courses) to transform multiple dimensions that determine the CSL (political, socioeconomic and legal levels, etc.). This is subsequently unfolded in the development of new instruments to combat the CSL, in the creation of legislation and related policies or their improvement and in the financial and economic penalization of perpetrators. These pressures even resulted in the creation of the Registry of Employers who submitted workers to slavery conditions - popularly known as the Dirty List of Slave Labor - and the improvement of legislation and definition of slavery, which resulted in a new wording of article 149 of the Brazilian Penal Code, approved at the end of 2003.

Regarding the support of vulnerable communities and victims of slavery, it is worth highlighting the creation of a platform for effective transformation of the reality of territories and regions where the CSL is spread, in a careful social and community monitoring, supported by inter-institutional networks of attention and surveillance (CDVDH/CB; CPT, 2017). It is known as the Integrated Action Network to Fight Against Slavery (RAICE), consisting in neighborhoods, communities and municipalities work "selected by the most intense frequency of enticement, migration, risk, to do the work connected with municipal institutions" (João). This practice is carried out through the formation of a "surveillance network" between the state and 
society that seeks to "propose actions and alternatives that can change the path of these workers [...] treating the case of these workers as a structural case" (João).

The notion that guides the RAICE project is the overcoming of the reductionist approach aimed at victims of slavery taken as isolated individuals, detached from a social, communitarian, structural reality, marked by the lack of guaranteed access to education, health and decent work, etc. The network seeks to expand the possibilities of social reinsertion, providing not only access to the formal labor market, but also overcoming vulnerabilities so that families can leave the slavery pathway.

The SMs consider that the problem of slavery is structural, historically built and pushes the poorest populations to the margins of society, reducing their chances and opportunities and denying their rights. To break this cycle, it would be necessary to strengthen networking actions, connecting local, state and federal government, the SMs, and the community in order to put in place a system of community surveillance of slavery (TOGNONI, 1997). These actions already take place in about 20 municipalities in the interior of Maranhão, Pará, Piauí, and Tocantins (CDVDH/CB; CPT, 2017) and seek to overcome the logic that the workers would be enslaved "because they are disqualified, and by qualifying them we will be able to propose them a decent job" (João).

In order to further strengthen the interventions, the SMs mobilize the creation of the Forum for the Eradication of Slave Labor in the state of Mato Grosso, uniting it with an already existing collective articulation in this state from the Henrique Trindade Center for Human Rights, and contributing to the development and performance of the State Commission for the Eradication of Slave Labor (COETRAE) and the Forum on Human Rights and Land, articulating CSL to land and migration issues.

These permanent, open, plural and diversified spaces strengthen the articulation of the SMs and the State in favor of the defense of vulnerable social groups, traditional peoples and communities wounded in the principles of citizenship and dignity, directly affected by the capitalist process of hegemonic development in its different expressions in Mato Grosso.

A final important point as an axis of intervention is the collaboration of the SMs jointly with the inspection of processes and work environments. In the Mato Grosso context, where the CSL is linked to the process of occupation of geographical space and colonization that generated land conflicts, violence and loss of territories 
of traditional populations, there are historical attempts to form coalitions to resist strong economic-oligarchic groups and create better conditions for the working class.

These actions were initiated in 1980, mainly in the Centro de Pastoral de Migrantes (Church Pastoral for Migrants Center) that received workers from the Northeast in the process of agricultural expansion in the state, but it was in the 1990s that there were more incisive attempts to insert SMs agents in the inspections of the Regional Superintendence of Labor of MT in work environments, with the objective of being the "society watch" and the "critical watch" to potentiate the inspections.

Here the operation of the VISAT principles - intersectorality and social participation - is clearly observed, because the entities working in the inspections pointed out the participation of "this entire team" in an effort of collaboration between state agencies (Public Ministry of Labor, Ministry of Labor) and SMs (CPT, Migrant Pastoral, Burnier Faith and Justice Center, and also some union entities of rural workers).

About these intervention practices, an important analogy emerges in an interview. The interviewee narrates that these collaborative actions with the participation of the SMS had the intention of being a "resounding board" (Gabriela). We interpret that this metaphor signals the potentiality of the SMs in exercising a function similar to the loudspeaker of a musical instrument, which reverberates, gives greater intensity to the sound waves and extends its reach and amplitude making the existence of the CSL more audible to varied audiences mobilizing more measures of defense of the workers.

The discourse of the SMs in the context of slave labor-conflict over land outlined here, therefore, points to the history, means, forms and purposes of a popular surveillance of contemporary slave labor (VPTEC), operated by SMs. It is evident that the CSL was constituted as a specific target of a surveillance cycle composed of original information generation processes and multiple forms of intervention not necessarily sequential, but systematic (Figure 1), aligned with the conception of VISAT in terms of a continuous and systematic action of analysis and intervention in the determinants and conditioning factors of work-related diseases (BRASIL, 1998). 
Figure 1. Mechanisms of popular surveillance of contemporary slavery

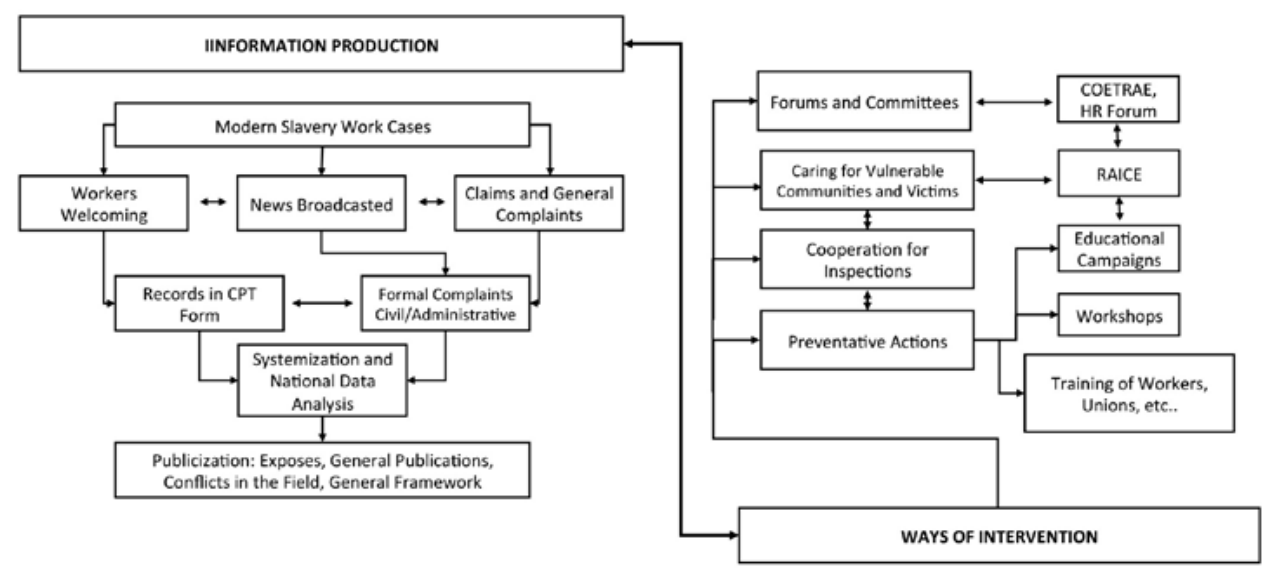

Source: Authors.

By interpreting this practice of SMs as a Popular Surveillance of Contemporary Slavery (Vigilância Popular do Trabalho Escravo Contemporâneo - VPTEC), from the point of view of its nature, we emphasize that it is not necessarily an state surveillance, because it is forged with a certain autonomy in relation to the instruments and devices of the State, while it also operates sometimes in cooperation with it (joint actions of inspection of the working environment), sometimes presenting demands to it (production of information to force the State to act), without ever being reduced and/or identifying to it. Furthermore, agents in operation have a differentiated commitment and engagement in relation to agents from State sectors in the field of health. They respond to workers' demands as a life commitment that leads to an incessant "watch" and engenders a state of constant alert to "not lose sight" of slavery situations. This activity goes far beyond professional actions in the sphere of an activity regulated by the labor contract.

Its main purpose is to provide knowledge and actions in the immediate interest of improving health and transforming the situation that determines illnesses and deaths (BROWN, 1992; BREILH, 2006) and, therefore, it can be considered an alternative epidemiology that seeks to identify outbreaks of occurrences, affected regions, characteristics of the population involved, forms of manifestation to open ways to liberate people from this social condition. 
This reinforces the notion that health production takes place beyond the State sphere, in the engagement and actions of SMs (BREILH, 2003). This collective action of dismantling oppressions and violence of the CS towards emancipation, equity and quality of life is primordial for building healthy societies. This is, therefore, an emancipatory vigilance that opens up new horizons and transforming paradigms, overcoming bureaucratic state activities restricted to the biopolitical control of populations (FOUCAULT, 2008).

As for the means of what is called here VPTEC, we highlight the fact that it is based on and guided by the knowledge of the experience of the SMs agents. In fact, this is the sense of "popular" employed here: people not specialized in epidemiology and surveillance leading processes of data production and interventions. This is the critical view of society, the critical knowledge that makes a comprehensive reading of the problem of CSL considering its causes and structural determinations and directing actions of different levels of unveiling and transformation.

In our view, therefore, the SMs' discourse points to approximations with what has been called popular epidemiology (PE) (BROWN, 1992). A popular epidemiology of contemporary slavery. PE begins with a group of people who observe the effects of a given situation and begin to share information among themselves, in successive processes of investigation and dialogue with representatives of the State, specialists, researchers, and lay people who correlate exposures and effects to community health (BROWN, 1992; 1993; 1997).

Within PE, the knowledge of "lay people" is fundamental for their capacity to apprehend and transform reality (NOVOTNY, 1994). In this sense, the agents of the SMs by mobilizing their knowledge, experiences and ways of seeing the world materialized also in practices of listening to the workers, solidarity, sharing, welcoming, etc., bring out "tangible evidence" (SCAMELL et al., 2009, p. 145) for their openness to meeting enslaved workers. Based on this, these SMs are able to produce original knowledge without dependence on specialists. Their "findings" are based on the concrete history of the subjects who narrate their experience in CSL and their sensory perceptions of exposure to violence, exhaustive journeys, degrading conditions, etc. These "tangible evidences" confer them legitimacy, amplifying the possibilities of public-State recognition and access to public policies (FASSIN, 2009). It should be noted that the practices of VPTEC, with denunciations, collection of evidence and formulation of intervention strategies at multiple levels forced the State 
to act and resulted in the insertion of the issue in the agenda of public policies and actions of various state sectors.

The recognition of the relevance of the knowledge of the SMs and social groups in this process deserves to be highlighted because we know that in health surveillance, instituted in the State spheres, there are many barriers that distance its practices from society as a whole (PORTO, 2017) by devaluing knowledge and practices of social groups, and in that way, reinforcing exclusionary processes crossed by the colonialism, patriarchy and capitalism of the modern project (PORTO, 2007). Therefore, it is necessary to emancipate health thinking itself and "decolonize Collective Health, surveillance and promotion practices" (PORTO, 2017, p. 3.157), operating the displacement of a positivist science that is the basis for sustaining specialized surveillance practices, hierarchized and closed to dialogue with sectors of society and social movements.

We need to recognize the validity of knowledge that is external to health services, universities and research centers, which express themselves in the social struggles against slavery in Brazil and act in the opposite logic to capitalist exploitation and large landowners. This recognition and action allow us to glimpse into the potential to move towards this emancipatory surveillance (PORTO, 2017) connected to a popular project. VPTEC reinforces democratization to reverse domination, contributing to break up with hegemonic visions in the field of health (BREILH, 2006).

Given the specific limitation and the programmatic-institutional vulnerability of the health sector, the popular vigilance extends the perspective beyond technicalism and incorporates greater dialogue and listening from the point of view of the subjects in their social context (ALVES, 2013). Thus, VPTEC values horizontality and collaboration in an alliance of SMs beyond a surveillance in the sense of punitive surveillance, seeking to be a counter-hegemonic network of defense of workers against other networks and alliances of Capital in their processes of exploitation.

As Alves (2013) pointed out, popular vigilance provides the promotion of dialogic actions whose intention is "to have a potential liberator of the ideological oppression of capital's civilization" (p. 186), fostering public policies of popular character.

We know that historically institutionalized health surveillance dates back to a militarized state context of the Cold War and still carries tensions that hampers the greatest "direct participation in the rights of notification, evaluation and right to know for citizens who are not health system workers" (CORREA FILHO, 2019, 
p. 980). We emphasize here that when SMs, in the struggle against CS, create the VPTEC cycle and build information networks, methodological training strategies, support vulnerable communities to the CSL, dialogue with society, put pressure on authorities and investigate working conditions in loco, they put into operation a relevant popular health responsibility that reinforces the importance of the participation of these collectives to guarantee the right to health of workers. After all, as Correa Filho (2019, p. 981) states: "without democracy and participatory popular committees, there is no Health Surveillance".

\section{Conclusion}

This paper demonstrated the existence of knowledge and practices of SMs organized as a popular surveillance of contemporary slavery, which manifests itself in a cycle of generation of information and multiple forms of intervention, sometimes pushing the state, sometimes collaborating with it in the defense of workers' rights. It is based on the knowledge of the SMs experience and values horizontality to the detriment of hierarchy, and is organized as a network of SMs spread throughout the Brazilian territory with the purpose of revealing situations of slavery and eradicating them.

Particularly, this surveillance is carried out in the detection-identification of slavery situations, in the reception of workers, in the articulation of groups/strategies in defense of workers, in the formulation of denunciations, records, analysis and publication of information on occurrences and impacts of slave labor, in the actions of inspection of work environments, prevention of new cases and strengthening of vulnerable communities and victims of slavery, organization of networks and collective forums of action. The action of these SMs, front and center of the land conflict, and alongside peasants, settlers and rural workers is part of the emancipatory process and produces information and actions in an organized and systematized way in conception and flow for this purpose.

This surveillance demonstrates a commitment to the cause of liberation from oppressions, whose strategies work as alert sentinels, representing the critical view of society, with the capacity to unite in spaces of discussion and formulation of inspection actions and forums of political potential, from conceptions and practices aligned with the Worker Health Surveillance. 
These pioneer actions to face slavery are a testimony to fundamental health practices of the worker in the Brazilian social scenario that should be acknowledged for not leaving a population of workers in invisibility and social fragility. At the same time, they challenge the National Health System (SUS) to insert the issue in its VISAT actions, to expand its connective links with the SMs and to increase dialogues with different knowledge and social groups from the multiple points of entry and connection with this important popular health practice in Brazil.

The panoramic view of the SMs experiences in the struggle for eradication of the CSL and the general lines of Popular Surveillance outlined here include many nuances and space-time specificities - since the CSL and anti-slavery struggles are not homogeneous and are permeated by tensions of historical and political conjunctures - that deserve new investigations that dig deeper on this topic and contribute to the strengthening of popular surveillance of health-work relations. ${ }^{1}$

\section{References}

ALVES, P. A. Vigilância popular da saúde: cartografia dos riscos e vulnerabilidades socioambientais no contexto de implantação da mineração de urânio e fosfato no Ceará. 2013. 243 f. Dissertação (Mestrado em Saúde Pública) - Universidade Federal do Ceará. Faculdade de Medicina, Fortaleza, 2013.

BALES, K. Disposable people: new slavery in the global economy. Berkeley, Los Angeles: University of California Press, 1999.

. Ending Slavery. How we free today's slaves. London, University of California Press, 2007.

BENACH, J. et al. The challenge of monitoring employment-related health inequalities. Journal Epidemiology Community Health, v. 66, n. 12, p. 1085-1087, 2012.

BRASIL. Lei no 10.803, de 11 de dezembro de 2003. Altera o art. 149 do Decreto Lei no 2.848, de 7 de dezembro de 1940 Código Penal. Diário Oficial [da] República Federativa do Brasil, Poder Executivo, Brasília, DF, 12 dez. 2003. Seção I, p. 1.

. Portaria no 1.823, de 23 de agosto de 2012. Diário Oficial [da] República Federativa do Brasil, Poder Executivo, Brasília, DF, 24 ago. 2012. Seção I, p. 46.

. Portaria no 3.120 , de $1^{\circ}$ de julho de 1998. Diário Oficial [da] República Federativa do Brasil, Poder Executivo, Brasília, DF, 14 jul. 1998. Seção I, p. 60.

BREILH, J. De la vigilancia convencional al monitoreo participativo. Ciência e Saúde Coletiva, Rio de Janeiro, v. 8, n.4, p. 937-951, 2003. 
. Epidemiologia crítica: ciência emancipadora e interculturalidade. Rio de Janeiro: Editora Fiocruz, 2006.

BROWN, P. Popular Epidemiology and Toxic Waste Contamination: Lay and Professional Ways of Knowing Source. Journal of Health and Social Behavior, v. 33, n. 3, p. 267-281, 1992.

. Popular epidemiology revisited. Current Sociology, v. 45, n. 7, p. 137-156, 1997.

. When the Public Knows Better: Popular Epidemiology Challenges the System.

Environment: Science and Policy for Sustainable Development, v. 35, n. 8, p. 16-41, 1993.

CENTRO DE DEFESA DA VIDAE DOS DIREITOS HUMANOS CARMEN BASCARÁN;

COMISSÃO PASTORAL DA TERRA (Orgs.). Por debaixo da floresta: Amazônia Paraense saqueada com trabalho escravo. São Paulo: Urutu-Branco, 2017.

CORREA FILHO, H. R. A utopia do debate democrático na Vigilância em Saúde. Saúde debate. Rio de Janeiro, v. 43, n. 123, p. 979-986, 2019.

COMISSÃO PASTORAL DA TERRA (CPT). Conflitos no Campo: Brasil - 2017. Goiânia: CPT Nacional, 2017. . Conflitos no campo: Brasil - 2019. Goiânia: CPT Nacional, 2020.

ESTERCI, N. Escravos da desigualdade: um estudo sobre o uso repressivo da força de trabalho hoje. Centro Edelstein de Pesquisas Sociais, 2008.

FASSIN, D. Another Politics of Life is Possible. Theory, Culture e Society, v. 26, n. 5, p. 44-60, 2009. FIGUEIRA, R. R. Pisando fora da própria sombra: a escravidão por dívida no Brasil contemporâneo. Rio de Janeiro: Civilização Brasileira, 2004.

FIGUEIRA, R. R.; PRADO, A. Trabalhadores denunciam o trabalho escravo. Hendu, v. 4, n. 1, p. 22-40, 2014.

FONTANELLA, B. J. B.; et.al. Amostragem em pesquisas qualitativas: proposta de procedimentos para constatar saturaçáo teórica. Cadernos de Saúde Pública. Rio de Janeiro. v. 27, n. 2, p. 389-394, 2011.

FOUCAULT, M. Arqueologia do saber. Rio de Janeiro: Forense Universitária, 2008.

. Nascimento da biopolitica: curso dado no Collège de France (1978-1979). Coleção Tópicos. São Paulo: Martins Fontes, 2008.

FREITAS, E. O.; RIBEIRO, A. M. M. O trabalho escravo contemporâneo e a CPT na Amazônia: memória e luta pela libertação. In: Encontro Anual da ANPOCS, 41., 2017, Caxambu-MG. Anais, 2017.

GOHN, M. G. Movimentos sociais na contemporaneidade. Revista Brasileira de Educaşão, Rio de Janeiro, v. 16, n. 47, p. 333-361, 2011. 
LEÃO, L. H. C. Trabalho escravo contemporâneo como um problema de saúde pública. Ciência e Saúde Coletiva, Rio de Janeiro, v. 21, n. 12, p. 3927-3936, 2016.

MARTINS, J. de S. Reforma Agrária: o impossível diálogo. São Paulo: Editora da Universidade de São Paulo, 2004.

MINISTÉRIO PÚBLICO DO TRABALHO. OBSERVATÓRIO DIGITAL DO TRABALHO ESCRAVO NO BRASIL. Smartlab de Trabalho Decente MPT-OIT. Disponível em: http://observatorioescravo.mpt.mp. Acesso em: 12 abr. 2019.

NOVOTNY, P. Popular epidemiology and the struggle for community health: alternative perspectives from the environmental justice movement. Capitalism Nature Socialism, v. 5, n. 2, p. 29-42, 1994.

PATTERSON, O. Slavery and Social Death. A comparative Study. Massachusetts: Harvard University Press, 1982.

PORTO, M. F. de S. Pode a Vigilância em Saúde ser emancipatória? Um pensamento alternativo de alternativas em tempos de crise. Ciência e saúde coletiva, Rio de Janeiro, v. 22, n. 10, p. 31493159, out. 2017.

SCAMELL, M. K. et al. Tangible evidence, trust and power: Public perceptions of community environmental health studies. Social Science e Medicine, v. 68, n. 1, p. 143-153, 2009.

SEVALHO, G. Apontamentos críticos para o desenvolvimento da vigilância civil da saúde. Physis: Revista de Saúde Coletiva, Rio de Janeiro, v. 26, n. 2, p. 611-632, 2016.

SILVA, M. P. O trabalho escravo contemporâneo e a atuação da CPT no campo (1970-1995). 264fl. Tese (Doutorado em História Social) - Pontifícia Universidade Católica de São Paulo, PUC-SP, 2016.

TODRES, J. Moving Upstream: The Merits of a Public Health Law Approach to Human Trafficking. North Carolina Law Review, v. 89, n. 2, p. 447-506, 2011.

TOGNONI, G. Manual de Epidemiologia Comunitaria. Edición CECOMET, 1997.

TOURAINE A. Na Fronteira dos Movimentos Sociais. Sociedade e Estado, Brasília, v. 21, n. 1, p. 17-28, 2006.

VASCONCELLOS, L. C. F.; PAIVA, M. J. Modelo Operário Italiano: o surgimento do campo da saúde do trabalhador. In: VASCONCELLOS, L. C. F.; OLIVEIRA, M. H. B. de. (Orgs.). Saúde, Trabalho e Direito: uma trajetória crítica e a crítica de uma trajetória. Rio de Janeiro: Educam, 2011.

ZIMMERMAN, C.; HOSSAIN, M.; WATTS, C. Human trafficking and health: A conceptual model to inform policy, intervention and research. Social Science e Medicine, v. 73, n. 2, p. 327-335, 2011. 


\section{Note}

${ }^{1}$ L. Leâo: conceived the research, carried out the analysis and writing of the article. T. A. Ribeiro: carried out field work, analysis and writing of the article. 


\section{Resumo}

\section{A vigilância popular do trabalho escravo contemporâneo}

Considerando os movimentos sociais (MS) como agentes de produção de informação e ação fundamentais para melhoria das condições de saúde dos trabalhadores e sua relevância na história das relaçôes saúdetrabalho no Brasil, o artigo analisa saberes e práticas de MS relativas a coleta, sistematização, divulgação de informações e açấo de intervenção na escravidão contemporânea na perspectiva da vigilância em saúde do trabalhador (VISAT). Realizou-se pesquisa exploratória de natureza qualitativa sobre práticas discursivas de MS na luta pela erradicação do trabalho escravo no Brasil. As entrevistas com militantes, documentos produzidos pelos MS e a observação de encontros e seminários foram analisadas aqui conforme o pensamento foucaultiano. Os resultados demonstram a existência de uma vigilância popular do trabalho escravo contemporâneo, operacionalizada por MS com mecanismos pioneiros e originais de coleta, sistematização e publicização de dados sobre ocorrências da escravidão associadas a estratégias de intervenção para a defesa da vida dos trabalhadores e trabalhadoras. Conclui-se que essa prática popular de vigilância da escravidão desafia o SUS a ampliar os diálogos com os diferentes saberes e MS para inserir a temática em suas ações de VISAT.

Palavras-chave: movimentos sociais; vigilância popular; saúde do trabalhador. 